IZA DP No. 8021

Procrastination, Academic Success and the Effectiveness of a Remedial Program

Maria De Paola

Vincenzo Scoppa

March 2014 


\title{
Procrastination, Academic Success and the Effectiveness of a Remedial Program
}

\author{
Maria De Paola \\ University of Calabria \\ and IZA
}
Vincenzo Scoppa
University of Calabria
and IZA

\section{Discussion Paper No. 8021 \\ March 2014}

IZA
P.O. Box 7240
53072 Bonn
Germany

\author{
Phone: +49-228-3894-0 \\ Fax: +49-228-3894-180 \\ E-mail: iza@iza.org
}

\begin{abstract}
Any opinions expressed here are those of the author(s) and not those of IZA. Research published in this series may include views on policy, but the institute itself takes no institutional policy positions. The IZA research network is committed to the IZA Guiding Principles of Research Integrity.

The Institute for the Study of Labor (IZA) in Bonn is a local and virtual international research center and a place of communication between science, politics and business. IZA is an independent nonprofit organization supported by Deutsche Post Foundation. The center is associated with the University of Bonn and offers a stimulating research environment through its international network, workshops and conferences, data service, project support, research visits and doctoral program. IZA engages in (i) original and internationally competitive research in all fields of labor economics, (ii) development of policy concepts, and (iii) dissemination of research results and concepts to the interested public.
\end{abstract}

IZA Discussion Papers often represent preliminary work and are circulated to encourage discussion. Citation of such a paper should account for its provisional character. A revised version may be available directly from the author. 


\section{ABSTRACT \\ Procrastination, Academic Success and the Effectiveness of a Remedial Program*}

Procrastination produces harmful effects for human capital investments and studying activities. Using data from a large sample of Italian undergraduates, we measure procrastination with the actual behaviour of students, considering the delay in finalizing their university enrolment procedure. We firstly show that procrastination is a strong predictor of students' educational achievements. This result holds true controlling for quite reliable measures of cognitive abilities, a number of background characteristics and indicators of students' motivation. Secondly, we investigate, using a Regression Discontinuity Design, the effects of a remedial program in helping students with different propensity to procrastinate. We show that the policy especially advantages students who tend to procrastinate, suggesting that also policies not directly aimed at handling procrastination can help to solve self-control problems.

JEL Classification: D03, I21, D91, J01, J24

Keywords: procrastination, self-control, time preferences, time consistency, impatience, human capital, academic success, dropout, remedial courses

Corresponding author:

Vincenzo Scoppa

Department of Economics, Statistics and Finance

University of Calabria

Via Ponte Bucci

87036 Arcavacata di Rende (Cosenza)

Italy

E-mail:v.scoppa@unical.it

\footnotetext{
* We are grateful to Sara Laurita and Antonella Caparelli for helping in the use of the data. We would like to thank Marco Alberto De Benedetto, Francesca Gioia, Michela Ponzo for useful comments and suggestions.
} 


\section{Introduction}

Many important economic decisions, such as investments in human capital, saving, search for a new job, health-related activities, originate costs and benefits that occur at different points in time. The standard economic theory assumes that individuals trade-off utilities in different time periods according to an exponentially declining discount factor $\delta^{t}$ : this formulation entails time consistent preferences.

However, a lot of empirical evidence shows that individual decisions are better described through present-biased preferences or a “quasi-hyperbolic” time discounting factor (Laibson, 1997; O’Donoghue and Rabin, 1999; DellaVigna, 2009) in which the overall individual utility function is represented as: $U_{t}=u_{t}+\beta \delta u_{t+1}+\beta \delta^{2} u_{t+2}+\ldots$ where $u$ is the per-period utility, $\delta$ is the standard discount factor and $\beta<1$ represents an "immediacy effect", that is, immediate benefits and costs are perceived as much more important than future ones. ${ }^{1}$ Therefore, individuals will tend to anticipate gratifications to the present and postpone costly activities to the future, strongly discounting the related future consequences of their current choices.

The "quasi-hyperbolic" utility function implies time-inconsistent preferences and self-control problems. For example, an individual with present-biased preferences, when confronted in the current period with an investment as studying (creating benefits in a distant future in terms of higher earnings related to better educational attainments) will tend to procrastinate the effort to the next period, and then delay yet again to the next one. ${ }^{2}$ Sophisticated individuals - predicting their future preferences and aware of their future self-control problems - will try to use commitment devices to overcome or attenuate procrastination whereas fully or partially naïve individuals will continue to procrastinate incurring important welfare losses.

Empirically, the role played by procrastination has been shown in relation to consumption and savings decisions (Laibson, 1997; Angeletos et al., 2001), credit card use (Ausubel, 1999), health club memberships (DellaVigna and Malmendier, 2005), telephone calls (Grubb, 2009).

Investments in human capital are activities in which the tendency to procrastinate can be particularly harmful for individual achievements and lifetime utility. Techniques to manage procrastination are suggested in the websites of many universities worldwide. ${ }^{3}$ However, there is little evidence on the relationship between procrastination and educational performance: among the few exceptions, the seminal work of Mischel, Shoda and Rodriguez (1989) analyzing self-control in 4-year old children and relating their ability to delay gratification with their future scholastic performance; the analysis of Wong (2008) showing how students' performance in two college courses is negatively correlated to students' self-reported tendency to procrastinate and to their degree of naïvete; the small-scale experiment carried out by Ariely and

\footnotetext{
${ }^{1}$ This is also called the $(\beta, \delta)$ formulation.

${ }^{2}$ Similarly, Akerlof (1991) derives procrastination from the unduly saliency of current costs with respect to future costs.

${ }^{3}$ See, for example, Harvard University, Procrastination - Bureau of Study Counsel - Harvard University; University of Pennsylvania, "One of These Days I'll Stop Procrastinating", "Battling the Block: Writing Through and Beyond Writer's Block”; University of Buffalo, “Overcoming Procrastination”; Cornell University, "Creating a Daily To-Do List".
} 
Wertenbroch (2002) (with about 60 students) finding that students facing exogenously imposed deadlines perform better than students who set autonomously deadlines, while students facing no deadlines at all show the worst academic performance.

On the other hand, a number of works have tried to investigate the relationship between time preferences and educational achievements. Golsteyn, Gronqvist and Lindahl (2013), using a Swedish longitudinal dataset linked to a survey on children's time preferences, highlight a substantial adverse impact of impatience on school performance. Castillo et al. (2011) show that children with higher discount rates are more likely to receive disciplinary referrals in school. Cadena and Keys (2011), using the National Longitudinal Survey of Youths (NLSY), find that individuals perceived as "restless" (as judged by the interviewer), a proxy for impatience, do worse in terms of educational attainments. De Paola and Gioia (2013), using data from a sample of Italian undergraduate students, find a negative relationship between time preferences and academic performance. In contrast to these findings, Bettinger and Slonim (2007) do not find among a sample of children any correlation between a measure of their time preferences and their school achievement.

Even if the tendency to procrastinate and time preferences are likely to be related (O'Donoghue and Rabin, 1999; Reuben, Sapienza and Zingales, 2007), the policy implications deriving from impatience are different from those deriving from procrastination: while choices related to a higher degree of impatience are rational, those deriving from procrastination are not fully rational and since they can produce negative effects on individual and social welfare finalized policy interventions might be required.

In this paper we focus on procrastination problems among Italian college students. We,firstly, investigate the relationship between procrastination attitudes and academic success. Secondly, we analyze to what extent an educational policy requiring students to attend some remedial courses has been effective for individuals with a tendency to procrastinate compared to others who typically do not procrastinate.

Many of the existing empirical investigations on the relationship between procrastination and individual outcomes rely on self-reported measures of procrastination, often obtained from surveys asking subjects about their tendency to accomplish a task immediately or to delay it. Another measure, especially used among psychologists, is to consider students' behavior in turning term papers (see for example, Solomon and Rothbaum 1984; Dewitte and Schouwenburg 2002; Howell et al. 2006): given their nature, these studies usually rely on very small samples.

In our work we use a measure of individual procrastination based on actual students' behavior rather than on survey questions, with the additional advantage of considering a quite large sample of students. We exploit the fact that in the University we consider, the admission decision is notified to all the applying students at the same time (through the university official website) and students have available seven weekdays to accomplish the enrollment procedure, which requires some bureaucratic tasks and the payment of an initial fee through bank or post office. ${ }^{4}$ These activities represent small but immediate transaction costs for students, in terms of time lost in filling the forms and in making the payment. Individuals with a tendency

\footnotetext{
${ }^{4}$ Credit card or on-line payment was not accepted.
} 
to procrastinate are likely to accomplish the task later in time or just before the deadline. Therefore, we consider as a proxy of individual procrastination the number of days a student takes to accomplish the enrollment procedure since the admission notification. This measure of procrastination is a reasonable behavioural counterpart of survey questions asking students about their tendency to "complete assignments immediately", “complete before deadline”, or "at the last possible moment”. Then, we assume that procrastination in carrying out this administrative task is predictive of a general tendency to procrastinate that we consider as a relatively stable and persistent characteristic of an individual.

The short time period that students had for accomplishing the bureaucratic procedures required for enrollment also allows to plausibly assume - in terms of the $(\beta, \delta)$ formulation - that the standard discount factor $\delta$ is equal to one. Therefore, with respect to existing works in which the impact of $\delta$ and $\beta$ cannot typically be separated, thanks to a reasonable measure of $\beta$, we are able to isolate the effects of self-control problems (which arise from limited rationality) from those arising from a pure time preference (consistent with full individual rationality).

Similar measures of procrastination are used by Reuben, Sapienza and Zingales (2007) who consider both the delay of students in cashing a check and the timing for the application to an MBA. Compared to their measures, our indicator is less likely to be affected by other factors apart from students' tendency to procrastinate. In fact, we do not consider the timing for the application to the Degree program, but the timing for accomplishing bureaucratic procedures once students' applications were accepted by their preferred degree course. These students are unlikely to be students scarcely motivated to enroll at university or uncertain about the Degree program to choose (we also present some robustness checks showing that neither motivation nor the availability of information are driving our results). In addition, given the very short time period of seven days that students had for finalizing their enrollment procedure, we can exclude that our measure is related to students' wealth or financial constraints (indeed our measure of procrastination is not correlated neither with parents' education nor with their economic conditions). ${ }^{5}$

In the first part of the paper we investigate whether academic achievements are correlated to procrastination. We find that, controlling for a number of individual characteristics, including cognitive abilities, students who tend to procrastinate obtain worse educational outcomes, both at the High School level (earning a lower Final Grade) and in terms of the number of credits acquired in their academic career. The tendency to procrastinate is also positively related to drop out decisions. These results hold true also when - using an alternative sample - we control for parents' education, family background and some measures of individual motivation.

Thus, our findings are in line with the recent literature (see, among other, Heckman and Rubinstein, 2001) stressing the importance of non-cognitive abilities for success in education and in the labor market.

\footnotetext{
${ }^{5}$ Novarese and Di Giovinazzo (2013) use a very similar measure of procrastination for students enrolled at a Degree Program in Law at an Italian University and find high rates of correlation between this variable and several measures of students' performance.
} 
The second part of our paper investigates whether an educational policy undertaken to help students to close their educational gaps is also effective to overcome procrastination problems. While the existing literature considers interventions directly aimed at reducing procrastination - such as binding deadlines or other commitment technologies (DellaVigna, 2009) - we show that also policies not directly aimed at solving self-control problems can produce positive effects on procrastinators. More precisely, we focus on a policy - adopted for our sample students in 2009-2010 - requiring freshmen students to attend some remedial courses at the beginning of the academic year. Assignment to remedial courses was based on the results obtained by the students at a placement test and only students who, in each field of study, were placed below a certain score were induced to take remedial courses. Relying on the cutoff rule adopted to assign students to the treatment, De Paola and Scoppa (2014) evaluate the effectiveness of the remedial program using a Fuzzy Regression Discontinuity Design. In this paper, instead, using the same identification strategy, we investigate whether the effects of the program were heterogeneous according to students' attitude to procrastinate.

Remedial courses and the related mentoring activities made soon salient to attending students the need to work hard to overcome their educational gaps. This type of awareness might reveal particularly relevant for subjects with a tendency to procrastinate. Furthermore, given the very small number of students in each class (maximum 40 students), these courses provided deadlines for studying activities (through exercises in classes, tutorials, homework, and so on) that induced students to provide effort on a regular basis: this mechanism might have changed students' studying habits and might result especially beneficial for procrastinators.

We firstly show that students just above and below the cutoff point (on which assignment to the remedial program was based) do not differ significantly in terms of their tendency to procrastinate. Then, we present both Intention to Treat effects and Local Average Treatment effects and show that the effectiveness of the remedial program was different according to students' propensity to procrastinate. We find that students who mostly benefit from the program are those with the strongest tendency to procrastinate. This finding is consistent with results emerging from Carrel and Sacerdote (2013) who show that a program offering monetary incentives and mentoring activities to high school students was especially helpful for individuals who tend to procrastinate.

The paper is organized as follows. In Section 2 we provide some background information and describe the data used in our empirical investigation. In Section 3 we analyze how students' educational outcomes are related to procrastination. Section 4 shows the different impact of remedial courses according to students' procrastination attitude. Section 5 concludes. 


\section{Data and Descriptive Statistics}

Our empirical analysis relies upon individual-level data using a sample of undergraduate students enrolled in the academic year 2009-2010 at the University of Calabria, a middle-sized public university located in the South of Italy. ${ }^{6}$ The students in our sample are enrolled in First Level Degree (FLD) courses offered within different fields (Economics, Pharmacy, Engineering, Humanities, Mathematics and the Natural Sciences, and Political Sciences). ${ }^{7}$

Starting from the $1^{\text {st }}$ to the $24^{\text {th }}$ August 2009, our sample students have applied for their preferred Degree program at the University of Calabria. Then, the University has evaluated students' applications. The evaluation procedure - mainly based on students' High School Grade - has led to a list of admitted students. This list was communicated to students through publication on the University website on September $9^{\text {th }}$. Therefore, all students who applied for a place were informed of the admission decision at the same time. Starting from the publication of admission decisions, admitted students had 7 weekdays to accomplish the enrolment procedure (from September $10^{\text {th }}$ to September $18^{\text {th }}$ ).

Students who did not accomplish their enrolment process were excluded and places left vacant were filled with students who were ranked lower at the first stage or by re-opening the application procedure. Given this procedure, after the first deadline, a number of students were admitted in Degree Programs ended up with vacant places after the accomplishment of the first stage of enrolment. In our analysis we exclude these students and we only consider students whose enrolment was completed until the first deadline. Students enrolled later may have ended up in Degree Programs that differ from those that they would have chosen as a first choice or could be characterized by other unobservable differences with respect to regularly enrolled students.

The enrolment procedure requires students to fill in a number of forms and to pay a first small part of the university fees (320 euros) through a payment at a Bank or a Post Office. We observe the day in which students have accomplished their enrolment procedure and on the basis of this information we build a measure of procrastination considering how this date was close to the deadline.

More precisely, our main variable Procrastination takes values from 1, for students who have accomplished their enrolment procedure the first day after the notification of admission, to 7 , for students accomplishing the procedure the last admissible day. As it is possible to see from Table 1, in which we report some descriptive statistics, students on average accomplish their enrolment procedure after 4 days from notification of admission. However, there is a quite large variability, with $12.4 \%$ of students enrolling within the two days following notification (we build a dummy variable No Procrastination equal to one when this

\footnotetext{
${ }^{6}$ The University of Calabria currently has about 33,000 students, who are enrolled in different Degree Courses and are at different levels of the Italian University system.

${ }^{7}$ Since reform in 2001, the Italian university system has been organized around three main levels: First Level Degrees (3 years legal duration), Second Level Degrees (further 2 years), and PhD Degrees. When starting their university career, students choose a field and within that field they enrol in a certain FLD course. In order to gain a FLD course, students have to obtain a total of 180 credits (each successfully accomplished exam gives a number of credits ranging from 1-10; dissertation carries also some credits).
} 
occurs), $43 \%$ of students who accomplish the enrolment procedure in the third or fourth day following notification (represented with the dummy Slight Procrastination) and $44.5 \%$ of students waiting until the last three days before the deadline (represented with the dummy Heavy Procrastination). ${ }^{8}$

The measure of procrastination we use should distinguish between students who in accomplishing a task do it soon, those who wait and those who do it at the last moment because of a binding deadline. Our assumption is that this measure of procrastination captures a quite stable and persistent characteristic of students and, hence, we investigate if this variable is correlated to past and present educational achievements. As we will show in the next section, this measure is not correlated neither to students' economic and cultural background, nor to their motivation in studying activities.

Thanks to the administrative data provided by the University of Calabria, we observe a number of students' characteristics, such as gender, province and municipality of residence, year of high school completion and some measures of ability (High School Grade, type of High School attended, performance at the placement test).

Our students are enrolled in 5 different fields of study offered at the University of Calabria: Economics (33\% of students), Pharmacy (13.8\%), Humanities (23.3\%), Mathematics and Natural Sciences (14.4\%), and Political Sciences (15.4\%). ${ }^{9}$ Females made up about $64.5 \%$ of the sample; High School Grade, ranging from 60 to 100, is on average 83; about 49\% of students attended a Lyceum (rather than a technical or vocational school) and about $26 \%$ of them enrolled at University not in the same year in which they graduated from High School (Older Student).

Table 1. Descriptive Statistics

\begin{tabular}{|c|c|c|c|c|c|}
\hline Variable & Obs & Mean & Std. Dev. & Min & Max \\
\hline Procrastination & 3335 & 4.275 & 1.557 & 1 & 7 \\
\hline No Procrastination & 3335 & 0.124 & 0.329 & 0 & 1 \\
\hline Slight Procrastination & 3335 & 0.431 & 0.495 & 0 & 1 \\
\hline Heavy Procrastination & 3335 & 0.445 & 0.497 & 0 & 1 \\
\hline Female & 3335 & 0.645 & 0.479 & 0 & 1 \\
\hline High School Grade & 3335 & 83.087 & 11.454 & 60 & 100 \\
\hline Lyceum & 3335 & 0.486 & 0.500 & 0 & 1 \\
\hline Age & 3335 & 19.987 & 3.615 & 18 & 55 \\
\hline Total Credits & 3335 & 49.598 & 38.896 & 0 & 126 \\
\hline Economics & 3335 & 0.331 & 0.471 & 0 & 1 \\
\hline Pharmacy & 3335 & 0.138 & 0.345 & 0 & 1 \\
\hline Humanities & 3335 & 0.233 & 0.423 & 0 & 1 \\
\hline Math and Natural Sciences & 3335 & 0.144 & 0.351 & 0 & 1 \\
\hline Political Sciences & 3335 & 0.154 & 0.361 & 0 & 1 \\
\hline Test Score & 3335 & -1.146 & 14.992 & -50 & 46.83 \\
\hline Older student & 3335 & 0.265 & 0.442 & 0 & 1 \\
\hline Effective Treatment (Hours & 3335 & 0.555 & 0.635 & 0 & 1.6 \\
\hline \multicolumn{6}{|c|}{ Attendance Remedial Courses/100) } \\
\hline Assigned Treatment & 3335 & 0.586 & 0.493 & 0 & 1 \\
\hline
\end{tabular}

\footnotetext{
${ }^{8}$ Our results are robust to different definitions of dummies for procrastination levels.

${ }^{9}$ We have decided to exclude students enrolled in Engineering from our analysis because all the students in this field, independently of their Test Score obtained, were encouraged to attend the remedial courses.
} 
We also have information on an additional measure of students' ability given by students' performance in a placement test. As explained above, the cohort of students we consider were involved in a remedial program promoted by the regional government of Calabria and financed by the European Social Fund. Assignment to remedial courses (consisting of 160 hours of lectures coping with mathematics and language skills and carried out at the beginning of the academic year) was based on the results obtained by students at a placement test and only students who, in each field of study, were placed below a certain score were advised to take the remedial program. We build a variable, Test Score ${ }_{i}$, as the percentage of correct answers given by student $i$ in the placement test and we subtract the threshold level fixed by each faculty to assign students to remediation so as to make students' scores homogeneous across different fields of study. In this way, a score of +1 indicates that the student is placed just above the threshold and he/she is not invited to attend the remedial courses, while a score of 0 or a negative score indicates that the student is below the threshold and is advised to attend the remedial courses. We define the dummy variable Assigned Treatment $t_{i}$, which takes the value of one if student $i$ has been assigned to the remedial courses (Test Score $_{i} \leq 0$ ) and zero otherwise. As shown in Table 1, 58.6\% of sample students were assigned to remedial courses (Assigned Treatment). However, since courses were strongly recommended but were not compulsory, compliance of students with the assignment rule was only partial. The average number of hours of remedial courses attended by students assigned to the treatment was 94 (out of 160) while the average of Effective Treatment for the whole sample is equal to 55 (to make easier to interpret the coefficients, we divide by 100 the number of hours).

We also have information on students' careers at university. As shown in Table 1, by the end of the second year of their Degree program, students had acquired about 49.6 credits (out of the 120 that they were expected to achieve). Exams are evaluated on a scale ranging from 18 (the minimum passing mark) to 30 cum laude (set equal to 31) and the average grade at passed exams was 23.9.

In a regression in which we consider as dependent variable Procrastination and as independent variables students' characteristics (results not reported) we find that students' tendency to procrastinate is negatively correlated to our measures of ability, High School Grade and Test Score, while we do not find any statistically significant correlation between gender, age and type of school attended. Since in Italy students with better family background typically attend Lyceums, we are reassured that our measure of procrastination does not catch factors that might be related to family economic conditions. ${ }^{10}$

We also find that students with a tendency to procrastinate are more likely to be assigned to treatment, but as we will discuss in section 4 this correlation vanishes when we control for students' performance at the placement test. Finally, as expected, among students assigned to treatment those with a tendency to procrastinate attend a smaller number of hours of remedial courses.

\footnotetext{
${ }^{10}$ We will provide further evidence on this issue in Section 3.1.
} 


\section{Procrastination and Academic Success}

In this Section we analyze how students educational outcomes are related to our measure of procrastination. We firstly investigate the relationship between procrastination and the final grade obtained by students at High School. The idea is that students who procrastinate devote less time and effort to studying activities (postponing costly activities in proximity of deadlines) and, as a consequence, obtain a worse performance.

As reported in Table 2, we find a strong negative relationship between High School Grade and procrastination. In column (1) in which we only consider as a regressor our continuous measure of procrastination, we find that each day of delay in accomplishing the enrolling procedure is associated to a reduction of 0.85 points in the High School Grade ( $t$-stat=-6.7). This coefficient becomes slightly smaller (0.73) when we add controls for gender, type of High School attended and the dummy variable Older Student (column 2). In column (3), to take into account that students living in different towns and cities may face different costs in the enrollment procedure (due to different bank services necessary for the payment of fee), we include municipal fixed effects: the coefficient attracted by our indicator of procrastination is still negative and highly statistically significant (at the 1 percent level).

In columns (4) and (5) instead of considering a continuous measure of procrastination, we use the two dummy variables Slight Procrastination and Heavy Procrastination (leaving as reference category No Procrastination). In both specifications (without and with municipal fixed effects) we find that a student who slightly procrastinates has obtained a High School Grade that is about 1.64 points lower $(t-s t a t=-2.7)$ compared to that obtained by a student who do not procrastinate. We also find that students who heavily procrastinate have obtained a High School Grade that is 3.35 point lower ( $t$-stat=-5.5) in comparison to students who do not procrastinate.

Table 2. OLS estimates. Procrastination and Past Scholastic Achievement. Dependent variable: High School Grade

\begin{tabular}{|c|c|c|c|c|c|}
\hline & $(1)$ & $(2)$ & (3) & (4) & (5) \\
\hline Procrastination & $\begin{array}{c}-0.852 * * * \\
(0.127)\end{array}$ & $\begin{array}{c}-0.734 * * * \\
(0.122)\end{array}$ & $\begin{array}{c}-0.822 * * * \\
(0.131)\end{array}$ & & \\
\hline Slight Procrastination & & & & $\begin{array}{c}-1.641 * * * \\
(0.607)\end{array}$ & $\begin{array}{c}-1.844 * * * \\
(0.648)\end{array}$ \\
\hline Heavy Procrastination & & & & $\begin{array}{c}-3.355^{* * *} \\
(0.607)\end{array}$ & $\begin{array}{c}-3.677 * * * \\
(0.653)\end{array}$ \\
\hline Female & & $\begin{array}{c}4.528 * * * \\
(0.404)\end{array}$ & $\begin{array}{c}4.824^{* * *} \\
(0.417)\end{array}$ & $\begin{array}{c}4.547 * * * \\
(0.406)\end{array}$ & $\begin{array}{c}4.854^{* * *} \\
(0.418)\end{array}$ \\
\hline Lyceum & & $\begin{array}{c}-0.217 \\
(0.384)\end{array}$ & $\begin{array}{c}0.072 \\
(0.419)\end{array}$ & $\begin{array}{c}-0.248 \\
(0.385)\end{array}$ & $\begin{array}{c}0.051 \\
(0.419)\end{array}$ \\
\hline Older student & & $\begin{array}{c}-4.699 * * * \\
(0.455)\end{array}$ & $\begin{array}{c}-4.205^{* * * *} \\
(0.464)\end{array}$ & $\begin{array}{c}-4.754 * * * \\
(0.454)\end{array}$ & $\begin{array}{c}-4.277 * * * \\
(0.463)\end{array}$ \\
\hline Constant & $\begin{array}{c}86.731 * * * \\
(0.579)\end{array}$ & $\begin{array}{c}84.655^{* * *} * \\
(0.666)\end{array}$ & $\begin{array}{c}84.596 * * * \\
(0.703) \\
\end{array}$ & $\begin{array}{c}83.736^{* * *} \\
(0.640) \\
\end{array}$ & $\begin{array}{c}83.524^{* * *} \\
(0.682)\end{array}$ \\
\hline Municipal Fixed Effects & NO & NO & YES & NO & YES \\
\hline Observations & 3335 & 3335 & 3325 & 3335 & 3325 \\
\hline Adjusted R-squared & 0.013 & 0.088 & 0.118 & 0.088 & 0.117 \\
\hline
\end{tabular}

Notes: The Table reports OLS estimates. Standard errors (reported in parentheses) are corrected for heteroskedasticity. The symbols ***, **, * indicate that coefficients are statistically significant, respectively, at the 1,5 , and 10 percent level. 
Then, we examine how procrastination is correlated to students' achievements at University. It has to be considered that procrastination if favored by the Italian university system in which students pay very low fees, can take the exams when they prefer (students have typically 5 or 6 dates in each academic year in which they can sit to an exam) and can retake the exams as many times as they like. These are probably among the main causes of the unusually long time employed by Italian students to graduate and the very high drop-out rates (see Dornbusch, Gentilini, and Giavazzi, 2000).

In Table 3 we present estimation results considering as outcome variable the number of credits acquired by students in the two first years at University. In column (1), reporting results without individual controls, we find that one day of delay in the enrollment procedure is associated to a reduction of 5.18 credits $(t$-stat=-12.3). This correlation becomes slightly smaller in magnitude when we add controls for individual characteristics and municipal fixed effects (column 2). The same results hold true in column (3), where we add field of study dummies and our measure of ability Test Score. ${ }^{11}$

In column (4), in which we include the basic set of our controls, we show that students who Slightly Procrastinate acquire 3.64 credits less in their academic career compared to students who do not procrastinate and that for students who are Heavy Procrastinators this reduction is much larger (about 12.8 credits). Results remain substantially unchanged when we include among regressors our full set of controls and municipal fixed effects (column 5).

\footnotetext{
${ }^{11}$ In these specifications we are probably "over-controlling” since procrastination - as we have seen above - has a direct impact on past educational achievements.
} 
Table 3. OLS Estimates. Procrastination and Achievement at University. Dependent variable: Number of Credits

\begin{tabular}{|c|c|c|c|c|c|}
\hline & $(1)$ & $(2)$ & (3) & $(4)$ & (5) \\
\hline Procrastination & $\begin{array}{c}-5.178 * * * \\
(0.422)\end{array}$ & $\begin{array}{c}-3.606^{* * * *} \\
(0.431)\end{array}$ & $\begin{array}{c}-3.527 * * * \\
(0.412)\end{array}$ & & \\
\hline Slight Procrastination & & & & $\begin{array}{l}-3.640 * \\
(2.132)\end{array}$ & $\begin{array}{c}-4.833^{* *} \\
(2.039)\end{array}$ \\
\hline Heavy Procrastination & & & & $\begin{array}{c}-12.874^{* * *} \\
(2.157)\end{array}$ & $\begin{array}{c}-13.169 * * * \\
(2.063)\end{array}$ \\
\hline Female & & $\begin{array}{c}5.793 * * * \\
(1.399)\end{array}$ & $\begin{array}{c}6.288^{* * *} \\
(1.405)\end{array}$ & $\begin{array}{c}5.750 * * * \\
(1.404)\end{array}$ & $\begin{array}{c}6.326 * * * \\
(1.410)\end{array}$ \\
\hline High School Grade & & $\begin{array}{c}1.002 * * * \\
(0.060)\end{array}$ & $\begin{array}{c}0.872 * * * \\
(0.064)\end{array}$ & $\begin{array}{c}1.010 * * * \\
(0.061)\end{array}$ & $\begin{array}{c}0.880 * * * \\
(0.064)\end{array}$ \\
\hline Lyceum & & $\begin{array}{c}\text { 7.301*** } \\
(1.372)\end{array}$ & $\begin{array}{c}5.428 * * * \\
(1.389)\end{array}$ & $\begin{array}{c}7.305^{* * *} \\
(1.376)\end{array}$ & $\begin{array}{c}5.423 * * * \\
(1.393)\end{array}$ \\
\hline Older student & & $\begin{array}{c}-7.735^{* * * *} \\
(1.541)\end{array}$ & $\begin{array}{c}-9.511 * * * \\
(1.479)\end{array}$ & $\begin{array}{c}-8.142 * * * \\
(1.543)\end{array}$ & $\begin{array}{c}-9.875^{* * * *} \\
(1.482)\end{array}$ \\
\hline Test Score & & & $\begin{array}{c}0.374 * * * \\
(0.051)\end{array}$ & & $\begin{array}{c}0.373 * * * \\
(0.051)\end{array}$ \\
\hline Pharmacy & & & $\begin{array}{c}-16.217 * * * \\
(2.035)\end{array}$ & & $\begin{array}{c}-16.360 * * * \\
(2.041)\end{array}$ \\
\hline Humanities & & & $\begin{array}{c}5.015^{* * *} \\
(1.816)\end{array}$ & & $\begin{array}{c}4.838 * * * \\
(1.821)\end{array}$ \\
\hline Math and Natural S S & & & $\begin{array}{c}-15.822^{* * *} \\
(1.987)\end{array}$ & & $\begin{array}{c}-15.688^{* * * *} \\
(1.993)\end{array}$ \\
\hline Political Sciences & & & $\begin{array}{c}6.583 * * * \\
(1.969)\end{array}$ & & $\begin{array}{c}6.722 * * * \\
(1.974)\end{array}$ \\
\hline Constant & $\begin{array}{c}71.734 * * * \\
(1.938)\end{array}$ & $\begin{array}{c}-23.513^{* * *} \\
(5.605)\end{array}$ & $\begin{array}{l}-9.263 \\
(5.981)\end{array}$ & $\begin{array}{c}-32.138 * * * \\
(5.527)\end{array}$ & $\begin{array}{c}-16.934 * * * \\
(5.916)\end{array}$ \\
\hline Municipal Fixed Effects & NO & YES & YES & YES & YES \\
\hline Observations & 3335 & 3325 & 3325 & 3325 & 3325 \\
\hline Adjusted R-squared & 0.043 & 0.180 & 0.254 & 0.177 & 0.250 \\
\hline
\end{tabular}

Notes: The Table reports OLS estimates. Standard errors (reported in parentheses) are corrected for heteroskedasticity. The symbols ***,**, * indicate that coefficients are statistically significant, respectively, at the 1,5 , and 10 percent level.

We also find that procrastination affects the probability of dropping out from university. Although we do not have direct information on whether students have decided to drop out of their university studies, we consider students who have not passed any exam over the first two years of their Degree program as students who have dropped-out or who are at strong risk of dropping out. Then, we use this information to define a dummy variable, Drop-out, that takes the value of one when the student has not passed any exam over the first and the second year of his/her academic career and 0 otherwise. We find that, controlling for the full set of our controls, an increase of one point in our measure of procrastination leads to an increase in the probability of dropping out of 3 percentage points, statistically significant at the 1 percent level. Moreover, students who heavily procrastinate have a higher probability of dropping out of 10 percentage points compared to students who do not procrastinate (results not reported to save space). ${ }^{12}$

\footnotetext{
${ }^{12}$ We also find a negative correlation (statistically significant at 5 percent level) between the average grade students obtained in the exams they passed and both Slight and Heavy Procrastination. The correlation between the average grade at passed exams and Procrastination is negative but statistically insignificant at usual levels.
} 


\subsection{Adding controls for family background and student motivation}

One may wonder whether our results are driven by some unobservable students' characteristics that are correlated both to their academic success and to our measure of procrastination. Unfortunately, for the cohort of students enrolled in 2009-2010 we do not have additional controls for students' characteristics. However, we have much richer data from the previous cohort (students enrolled in 2008-2009). For these students, thanks to an on-line survey proposed to students at the moment of their enrollment, we have some information on student's family background. Therefore, we can build a number of variables to take into account additional students' characteristics and investigate whether these characteristics affect the estimated relationship between procrastination and educational achievements.

Using information from survey questions we compute a variable Parents' Education which is the average number of years of education acquired by students' parents, ${ }^{13}$ two dummy variables Father Unemployed and Mother Unemployed to take into account whether the student's parents are unemployed. We also have information on whether students were employed at the moment of their enrolment at University, which we use to build a dummy variable Employed (8\% of sample students).

The correlation between Procrastination (which for the 2008-2009 cohort has been computed as described above and takes values in the range 1-7) and our measures of family background is generally weak. For instance, the correlation between Parents' Education and Procrastination is 0.003 ( $p$-value=0.88), while the correlation between Procrastination and Father Unemployed is 0.028 ( $p$-value $=0.13$ ). ${ }^{14}$ Finally, the correlation between Employed and Procrastination is positive (0.029) and statistically significant at the 10 percent level ( $p$-value $=0.10$ ), probably because employed students are busier and for this reason tend to delay the accomplishment of the enrollment procedure. All in all, this evidence confirms that our measure of procrastination does not catch factors that might be related to family economic conditions.

In Table 4 we report our estimation results for the 2008-2009 cohort of students considering as dependent variable the Number of Credits acquired in the two years following enrollment. ${ }^{15}$ In column (1) we replicate specification (3) of Table 3. Also for this cohort of students, Procrastination is negatively correlated to the Number of Credits: the coefficient is similar in magnitude to that found in estimates reported in Table 3.

As shown in column (2), results do not qualitatively change when we add controls for family background and the dummy variable Employed. Our measures of family background are not statistically significant. This is probably due to the fact that these variables are highly correlated with measures of student's cognitive ability and educational choices. For instance, the correlation between Parents' Education and High School Grade is 0.059 (statistically significant at the 1 percent level). Even stronger is the correlation between Parents' Education and the type of school attended (Lyceum): 0.324, $p$-value=0.00,

\footnotetext{
${ }^{13}$ The number of years of education of students' mother and father are highly correlated (0.62, statistically significant at the 1 percent level). For this reason we do not consider them as separate regressors.

${ }^{14}$ The correlation between Procrastination and Mother Unemployed is -0.003 ( $p$-value $=0.86$ ).

${ }^{15}$ Results similar to those reported in Table 2 are found when we consider as dependent variable the High School Grade and add controls for family background and student's employment status (results are not reported).
} 
confirming that in Italy individuals from wealthier families typically attend a Lyceum, while those with a poorer background enroll in vocational schools (see, for example, Checchi, Fiorio, Leonardi, 2008). This tendency is also supported by the negative correlation we find between Father Unemployed and Lyceum (0.093, $p$-value=0.00).

To confirm this, in column (3) we estimate a specification in which we control for family background but we exclude from regressors High School Grade, Lyceum and Test Score. Without controlling for students' measures of cognitive ability, we find that the Number of Credits is positively affected by Parents' Education and negatively affected by the dummy variable Employed (denoting whether the student's was working at the moment of his/her enrollment at University).

In columns (4) and (5) of Table 4 we replicate specifications (1) and (2), but we measure procrastination using the two dummy variables Slight Procrastination and Heavy Procrastination. We find that both Slight Procrastination and Heavy Procrastination are negatively and statistically significantly correlated to the Number of Credits. Remarkably, these estimates are very similar in the two specifications and very close to those found for the cohort 2009-2010. Controlling for the full set of variables in column (5), students who slightly procrastinate acquire about 3.9 credits less compared to students who do not procrastinate, while those who heavily procrastinate acquire about 12 credits less.

In principle the choice to accomplish the enrollment procedure close to the deadline could be determined by lack of motivation or uncertainty about which field of study to choose or the advisability of going to university at all. However, since we only consider students who were admitted in their preferred Degree program and the time span for finalizing the enrollment procedure was very short, these factors should not play a very relevant role. Furthermore, to better investigate whether the relationship between our measure of procrastination and academic performance is related to motivational factors, we consider a number of additional information provided by our survey data on students' motivation and beliefs at the moment of their enrolment at university. 
Table 4. Procrastination, Achievement and Family Background. OLS Estimates Dependent variable: Number of Credits. Student enrolled in 2008-2009

\begin{tabular}{|c|c|c|c|c|c|c|c|}
\hline & (1) & $(2)$ & (3) & (4) & (5) & $(6)$ & (7) \\
\hline Procrastination & $\begin{array}{c}-3.338 * * * \\
(0.610)\end{array}$ & $\begin{array}{c}-3.305^{* * *} \\
(0.611)\end{array}$ & $\begin{array}{c}-4.254 * * * \\
(0.670)\end{array}$ & & & $\begin{array}{c}-3.254 * * * \\
(0.610)\end{array}$ & \\
\hline Slight & & & & $-3.883 * *$ & $-3.877 * *$ & & $-3.751 * *$ \\
\hline Procrastination & & & & (1.769) & $(1.772)$ & & $(1.770)$ \\
\hline Heavy & & & & $-12.076^{* * *}$ & $-11.947 * * *$ & & $-11.795 * * *$ \\
\hline Procrastination & & & & $(2.267)$ & $(2.273)$ & & $(2.269)$ \\
\hline Female & $\begin{array}{c}6.927 * * * \\
(1.612)\end{array}$ & $\begin{array}{c}6.679 * * * \\
(1.629)\end{array}$ & $\begin{array}{c}13.146^{* * *} \\
(1.709)\end{array}$ & $\begin{array}{c}6.756^{* * *} \\
(1.613)\end{array}$ & $\begin{array}{c}6.519 * * * \\
(1.630)\end{array}$ & $\begin{array}{c}6.385 * * * \\
(1.636)\end{array}$ & $\begin{array}{c}6.192^{* * *} \\
(1.637)\end{array}$ \\
\hline High School Grade & $\begin{array}{c}0.995 * * * \\
(0.072)\end{array}$ & $\begin{array}{c}0.994 * * * \\
(0.072)\end{array}$ & & $\begin{array}{c}1.002 * * * \\
(0.072)\end{array}$ & $\begin{array}{c}1.000 * * * \\
(0.072)\end{array}$ & $\begin{array}{c}0.970 * * * \\
(0.072)\end{array}$ & $\begin{array}{c}0.975^{* * *} \\
(0.072)\end{array}$ \\
\hline Lyceum & $\begin{array}{c}8.650^{* * *} \\
(1.545)\end{array}$ & $\begin{array}{c}8.752 * * * \\
(1.628)\end{array}$ & & $\begin{array}{c}8.783 * * * \\
(1.546)\end{array}$ & $\begin{array}{c}8.877 * * * \\
(1.629)\end{array}$ & $\begin{array}{c}7.863 * * * \\
(1.663)\end{array}$ & $\begin{array}{c}7.944^{* * *} \\
(1.664)\end{array}$ \\
\hline Older student & $\begin{array}{c}-5.358 * * * \\
(1.888)\end{array}$ & $\begin{array}{c}-5.007 * * * \\
(1.935)\end{array}$ & $\begin{array}{c}-10.659 * * * \\
(2.055)\end{array}$ & $\begin{array}{c}-5.119 * * * \\
(1.890)\end{array}$ & $\begin{array}{c}-4.779 * * \\
(1.937)\end{array}$ & $\begin{array}{c}-4.137 * * \\
(1.949)\end{array}$ & $\begin{array}{c}-3.876 * * \\
(1.951)\end{array}$ \\
\hline Test Score & $\begin{array}{c}0.375^{* * *} \\
(0.060)\end{array}$ & $\begin{array}{c}0.378 * * * \\
(0.060)\end{array}$ & & $\begin{array}{c}0.372^{* * *} \\
(0.060)\end{array}$ & $\begin{array}{c}0.375^{* * *} \\
(0.061)\end{array}$ & $\begin{array}{c}0.371^{* * *} \\
(0.060)\end{array}$ & $\begin{array}{c}0.368 * * * \\
(0.061)\end{array}$ \\
\hline Parents' Education & & $\begin{array}{l}-0.082 \\
(0.108)\end{array}$ & $\begin{array}{c}0.240 * * \\
(0.114)\end{array}$ & & $\begin{array}{l}-0.079 \\
(0.108)\end{array}$ & $\begin{array}{l}-0.106 \\
(0.109)\end{array}$ & $\begin{array}{l}-0.103 \\
(0.109)\end{array}$ \\
\hline Father Unemployed & & $\begin{array}{l}-1.234 \\
(2.759)\end{array}$ & $\begin{array}{l}-3.205 \\
(3.037)\end{array}$ & & $\begin{array}{l}-1.112 \\
(2.761)\end{array}$ & $\begin{array}{l}-1.932 \\
(2.712)\end{array}$ & $\begin{array}{l}-1.882 \\
(2.713)\end{array}$ \\
\hline Mother Unemployed & & $\begin{array}{c}0.589 \\
(2.218)\end{array}$ & $\begin{array}{l}-0.024 \\
(2.383)\end{array}$ & & $\begin{array}{c}0.552 \\
(2.218)\end{array}$ & $\begin{array}{c}0.591 \\
(2.216)\end{array}$ & $\begin{array}{c}0.572 \\
(2.216)\end{array}$ \\
\hline Employed & & $\begin{array}{l}-2.800 \\
(2.701)\end{array}$ & $\begin{array}{c}-6.106^{* *} \\
(2.958)\end{array}$ & & $\begin{array}{c}-2.729 \\
(2.703)\end{array}$ & $\begin{array}{l}-1.154 \\
(2.754)\end{array}$ & $\begin{array}{l}-1.039 \\
(2.756)\end{array}$ \\
\hline Well Informed & & & & & & $\begin{array}{l}-0.421 \\
(1.632)\end{array}$ & $\begin{array}{c}-0.719 \\
(1.632)\end{array}$ \\
\hline No Doubts & & & & & & $\begin{array}{c}3.154 * * \\
(1.550)\end{array}$ & $\begin{array}{c}3.380 * * \\
(1.550)\end{array}$ \\
\hline Planned Attendance & & & & & & $\begin{array}{c}4.759 * * * \\
(1.705)\end{array}$ & $\begin{array}{c}4.642^{* * *} \\
(1.705)\end{array}$ \\
\hline $\begin{array}{l}\text { Municipal Fixed } \\
\text { Effects }\end{array}$ & YES & YES & YES & YES & YES & YES & YES \\
\hline Observations & 3117 & 3117 & 3117 & 3117 & 3117 & 3117 & 3117 \\
\hline Adjusted R-squared & 0.277 & 0.276 & 0.172 & 0.276 & 0.276 & 0.279 & 0.278 \\
\hline
\end{tabular}

Note. In all specifications we control for field of study dummies (not reported to save space). The symbols ***, **, * indicate that coefficients are statistically significant, respectively, at the 1, 5, and 10 percent level.

We know whether students - according to their answers - at the moment of enrollment had adequate information on the Degree program they have chosen. ${ }^{16}$ About $76 \%$ of sample students declared to be Well Informed about their educational choice. In addition, 55\% of students stated that they had no doubts at all about the opportunity to enroll at university (No Doubts). ${ }^{17}$ We also have an additional indicator of students' motivation (Planned Attendance) obtained using a question asking students about their intention to attend teaching classes (about 79\% of students stated that they will attend all the teaching classes held in their

\footnotetext{
${ }^{16}$ We build this variable using the following question in the survey "Do you think the information you had available about the Degree Program you have chosen was: a) Very Adequate, b) Adequate, c) Inadequate, d) Very Inadequate. The dummy variable Well Informed takes the value of one for students answering "Very Adequate" or "Adequate" and 0 otherwise.

${ }^{17}$ We build this variable using the following question proposed in the survey "Have you had any doubt about the decision to acquire a University degree?” Four answers were possible: a) No doubts, b) Few doubts, c) Some doubts, d) Many doubts. The dummy variable No Doubts takes the value of one for students answering "No doubts" and 0 otherwise.
} 
Degree program). Well Informed and Planned Attendance are not correlated with our indicator of procrastination ( $p$-values are, respectively, 0.22 and 0.86 ) while the correlation between No Doubts and Procrastination is negative and statistically significant at the 5 percent level $(p$-value $=0.05)$.

In columns (6) and (7) of Table 4 we add these variables among regressors. In column (6) we measure procrastination using the days of delay in accomplishing the enrollment procedure. We find that both No Doubts and Planned Attendance are positively correlated to the number of credits acquired by students, but the magnitude and significance of the coefficient on Procrastination does not change when we add these controls (compare with column 2). Results remain almost unchanged in column (7) when we consider as measures of procrastination the two dummy variables Slight Procrastination and Heavy Procrastination.

All in all, these results suggest that our measure of procrastination is capturing neither students' background nor his/her degree of motivation or uncertainty in attending university.

\section{Procrastination and the Effectiveness of Remedial Courses}

Our sample students enrolled in 2009-2010 were involved in a remedial program financed by the European Social Fund and aimed at improving students' basic competences through an intensive training program offering a number of courses in subjects such as mathematics and language skills (for a total of 160 hours of teaching activities).

The effects of this program were evaluated in De Paola and Scoppa (2014), who show that the program produced beneficial effects. In this Section we investigate whether these effects differ according to students' tendency to procrastinate. ${ }^{18}$

Assignment to remedial courses was based on the results obtained by the students at a placement test and only students who, in each field of study, were placed below a certain score were advised to take remedial courses. As in De Paola and Scoppa (2014), to take into account that compliance was only partial, with some of the subjects assigned to the treatment deciding not to participate in the educational program (“no-shows”), we use a Fuzzy Regression Discontinuity Design in which the treatment status is probabilistically determined as a discontinuous function of the Test Score (the exogenous assignment to the treatment is used as an instrument for effective participation in the remedial courses). More precisely, we estimate the following model:

$$
\begin{aligned}
& Y_{i}=\beta_{0}+\beta_{1} \text { EffectiveTreatment }_{i}+\beta_{2} \text { EffectiveTreatment }_{i} *\left({\text { Procrastination })+\beta_{3} \text { Procrastination }}_{+} \beta_{4} f\left(\text { Test Score }_{i}\right)+\beta_{5} X_{i}+\mu_{k}+\varepsilon_{i}\right.
\end{aligned}
$$

$$
\begin{aligned}
& \text { EffectiveTreatment } \left._{i}=\pi_{0}+\pi_{1} \text { AssignedTreatment }_{i}+\pi_{2} \text { AssignedTreatment }_{i} * \text { ( } \text { Procrastination }\right) \\
& +\pi_{3} \text { Procrastination }+\pi_{4} g\left(\text { Test } \text { Score }_{i}\right)+\pi_{5} X_{i}+\mu_{k}+v_{i}
\end{aligned}
$$

\footnotetext{
18 Some recent empirical studies have evaluated the effects of remedial courses using US data (Bettinger and Long, 2009; Martorell and McFarlin, 2011; Calcagno and Long, 2010).
} 
where $Y_{i}$ is the performance of student measured as the number of credits earned, Effective Treatment is a variable measuring the number of hours of remedial courses attended; Effective Treatment*Procrastination is an interaction term between the number of hours of remedial courses attended and our measure of procrastination (demeaned), $f\left(\right.$ Test $\left._{\text {Score }}\right)$ and $g\left(\right.$ Test $\left._{\text {Score }}\right)$ ) are two flexible functional forms relating Test Score, respectively, to academic outcomes and participation to Effective Treatment; $X_{i}$ is a vector of individual characteristics (gender, High School Grade, Lyceum, province of residence, Older Student), which we use to increase the precision of estimates; $\mu_{k}$ are field of study dummies to take any difference across fields into account; $\varepsilon_{i}$ and $v_{i}$ are random error terms.

Equation [2] represents the first stage of the relationship between the student's effective participation in remedial courses and the score obtained at the placement test. The parameter $\pi_{1}$ is the effect of the Assigned Treatment on the effective participation in the remedial courses. Assigned Treatment*Procrastination is the interaction between our instrument and the procrastination indicator.

We firstly check the crucial assumption underlying the RDD approach, that is, we show that students just above and below the cutoff point do not differ significantly in terms of tendency to procrastinate. ${ }^{19}$ To investigate this issue we run a number of Discontinuity Regressions using as a dependent variable our measure of Procrastination, that is, we regress Procrastination on the dummy Assigned Treatment and control for Test Score and field of study dummies.

The estimation results are reported in Table 5. While using a first and second order polynomial of Test Score in columns (1) and (2) we find that there is a jump for the variable Procrastination at the cutoff point, using a third order polynomial in column (3) we show that Procrastination does not show any jump at the cutoff point. Furthermore, in columns (4), (5) and (6) we run Local Linear Regressions focusing on three different bandwidths considering respectively students with a Test Score ranging from -10 to $+10,-7 /+7$ and $-5 /+5$ points around the cut-off point. We find again that Assigned Treatment does not produce any statistically significant effect on our measure of procrastination.

${ }^{19}$ The balance checks for the other explanatory variables are provided in De Paola and Scoppa (2014). 
Table 5. Balance Checks. Regression Discontinuity Estimates. Dependent Variable: Procrastination

\begin{tabular}{lcccccc}
\hline \hline & $(1)$ & $(2)$ & $(3)$ & $(4)$ & $(5)$ & $(6)$ \\
\hline Assigned Treatment & $0.202^{* *}$ & $0.197^{* *}$ & 0.050 & 0.069 & -0.105 & -0.206 \\
& $(0.089)$ & $(0.089)$ & $(0.107)$ & $(0.140)$ & $(0.165)$ & $(0.187)$ \\
Test Score & -0.001 & -0.001 & $-0.012^{* *}$ & -0.011 & $-0.042^{* *}$ & $-0.056^{*}$ \\
& $(0.003)$ & $(0.003)$ & $(0.006)$ & $(0.012)$ & $(0.020)$ & $(0.030)$ \\
$($ Test Score)^2 & & -0.000 & $-0.000^{*}$ & & & \\
& & $(0.000)$ & $(0.000)$ & & & \\
(Test Score)^3 & & $0.000^{* *}$ & & & \\
& & & $(0.000)$ & & & \\
\hline Observations & 3335 & 3335 & 3335 & 1692 & 1260 & 970 \\
Adjusted R-squared & 0.040 & 0.040 & 0.042 & 0.032 & 0.041 & 0.038 \\
\hline \hline
\end{tabular}

Notes: The Table reports RDD estimates. Standard errors (reported in parentheses) are corrected for heteroskedasticity. The symbols $* * *, * *, *$ indicate that coefficients are statistically significant, respectively, at the 1,5 , and 10 percent level.

Reassured by these results we investigate whether the program has produced different effects according to students' tendency to procrastinate. We firstly present Intention to Treat Effects and then TSLS estimates from a Fuzzy Regression Discontinuity Approach.

\subsection{Intention to Treat Effects}

To recover the Intention to Treat effects, we use a Sharp Regression Discontinuity Design in which the treatment status is simply defined by the placement rule (Imbens and Lemieux, 2008; Angrist and Pischke, 2009), which corresponds to the reduced form of our model (equations 1 and 2):

$$
\begin{aligned}
& Y_{i}=\phi_{0}+\phi_{1} \text { AssignedTreatment }_{i}+\phi_{2} \text { AssignedTreatment }_{i} * \text { Procrastination }_{i}+\phi_{3} \text { Procrastination }_{i} \\
& +\phi_{4} f\left(\text { Test }_{\text {Score }}\right)+\phi_{5} X_{i}+\mu_{k}+\varepsilon_{i}
\end{aligned}
$$

We use the interaction term AssignedTreatment $_{i}^{*}$ Procrastination $_{i}$ to test whether the assignment to the treatment produces different outcomes for students with different propensity to procrastinate. Estimation results are reported in Table 6. In the first column, in which we control for a linear polynomial of Test Score, we find (in line with our previous estimates) that students' performance reduces with procrastination ( $t$-stat=-4.59). However, being assigned to treatment is especially beneficial for students with a tendency to procrastinate above the mean: the interaction term between Assigned Treatment and Procrastination (demeaned) is positive and highly statistically significant. More precisely, assignment to treatment leads to an increase of about 5 credits for an average student, while the effect is about 6.6 credits $(5.05+1.61)$ for students with a tendency to procrastinate one point higher than the average. Similar results emerge also in columns (2) and (3) in which we control, respectively, for second and third order polynomial of Test Score.

Very similar results are also obtained in estimates reported in columns (4), (5) and (6) in which, in order to not to impose any restriction on the underlying conditional forms, we include among controls interaction terms between the polynomial terms of Test Score and Assigned Treatment. 
Table 6. Remedial Courses and Procrastination. Regression Discontinuity Estimates. Intention to Treat Effects

\begin{tabular}{|c|c|c|c|c|c|c|}
\hline & $(1)$ & $(2)$ & $(3)$ & $(4)$ & $(5)$ & $(6)$ \\
\hline Assigned Treatment & $\begin{array}{c}5.053^{* *} \\
(2.017)\end{array}$ & $\begin{array}{c}5.391 * * * \\
(2.004)\end{array}$ & $\begin{array}{c}6.669 * * * \\
(2.423)\end{array}$ & $\begin{array}{c}6.012 * * * \\
(2.026)\end{array}$ & $\begin{array}{l}7.130^{* *} \\
(2.804)\end{array}$ & $\begin{array}{c}8.591^{* *} \\
(3.599)\end{array}$ \\
\hline Assigned Treatment*Procrastination & $\begin{array}{l}1.612^{* *} \\
(0.773)\end{array}$ & $\begin{array}{l}1.554^{* *} \\
(0.772)\end{array}$ & $\begin{array}{l}1.562 * * \\
(0.772)\end{array}$ & $\begin{array}{l}1.528 * * \\
(0.773)\end{array}$ & $\begin{array}{c}1.575^{* *} \\
(0.773)\end{array}$ & $\begin{array}{l}1.585^{* *} \\
(0.773)\end{array}$ \\
\hline Procrastination & $\begin{array}{c}-4.595^{* * *} \\
(0.604)\end{array}$ & $\begin{array}{c}-4.527 * * * \\
(0.604)\end{array}$ & $\begin{array}{c}-4.516^{* * *} \\
(0.605)\end{array}$ & $\begin{array}{c}-4.521^{* * *} \\
(0.605)\end{array}$ & $\begin{array}{c}-4.521^{* * *} \\
(0.605)\end{array}$ & $\begin{array}{c}-4.530 * * * \\
(0.605)\end{array}$ \\
\hline Test Score & $\begin{array}{c}0.475 * * * \\
(0.073)\end{array}$ & $\begin{array}{c}0.470 * * * \\
(0.071)\end{array}$ & $\begin{array}{c}0.566 * * * \\
(0.124)\end{array}$ & $\begin{array}{c}0.755 * * * \\
(0.103)\end{array}$ & $\begin{array}{l}0.595^{*} \\
(0.311)\end{array}$ & $\begin{array}{c}1.167 \\
(0.712)\end{array}$ \\
\hline Female & $\begin{array}{c}6.314 * * * \\
(1.312)\end{array}$ & $\begin{array}{c}6.441 * * * \\
(1.307)\end{array}$ & $\begin{array}{c}6.484 * * * \\
(1.306)\end{array}$ & $\begin{array}{c}6.419 * * * \\
(1.307)\end{array}$ & $\begin{array}{c}6.487 * * * \\
(1.307)\end{array}$ & $\begin{array}{c}6.474 * * * \\
(1.307)\end{array}$ \\
\hline High School Grade & $\begin{array}{c}0.876^{* * *} \\
(0.058)\end{array}$ & $\begin{array}{c}0.876 * * * \\
(0.058)\end{array}$ & $\begin{array}{c}0.876 * * * \\
(0.058)\end{array}$ & $\begin{array}{c}0.877 * * * \\
(0.058)\end{array}$ & $\begin{array}{c}0.875 * * * \\
(0.058)\end{array}$ & $\begin{array}{c}0.876 * * * \\
(0.058)\end{array}$ \\
\hline Lyceum & $\begin{array}{c}6.110^{* * * *} \\
(1.263)\end{array}$ & $\begin{array}{c}6.038 * * * \\
(1.264)\end{array}$ & $\begin{array}{c}6.011^{* * *} \\
(1.264)\end{array}$ & $\begin{array}{c}6.019 * * * \\
(1.265)\end{array}$ & $\begin{array}{c}6.015^{* * *} \\
(1.264)\end{array}$ & $\begin{array}{c}6.052 * * * \\
(1.263)\end{array}$ \\
\hline Older student & $\begin{array}{c}-9.192 * * * \\
(1.433)\end{array}$ & $\begin{array}{c}-9.182^{* * *} \\
(1.429)\end{array}$ & $\begin{array}{c}-9.211^{* * *} \\
(1.428)\end{array}$ & $\begin{array}{c}-9.175^{* * *} \\
(1.429)\end{array}$ & $\begin{array}{c}-9.211^{* * *} \\
(1.429)\end{array}$ & $\begin{array}{c}-9.240^{* * *} \\
(1.431)\end{array}$ \\
\hline$(\text { Test Score })^{\wedge} 2$ & & $\begin{array}{c}0.008 * * * \\
(0.002)\end{array}$ & $\begin{array}{c}0.009 * * * \\
(0.002)\end{array}$ & & $\begin{array}{c}0.005 \\
(0.008)\end{array}$ & $\begin{array}{c}-0.033 \\
(0.043)\end{array}$ \\
\hline$(\text { Test Score })^{\wedge} 3$ & & & $\begin{array}{c}-0.000 \\
(0.000)\end{array}$ & & & $\begin{array}{c}0.001 \\
(0.001)\end{array}$ \\
\hline Assigned Treatment*Test Score & & & & $\begin{array}{c}-0.518^{* * *} \\
(0.130)\end{array}$ & $\begin{array}{c}0.125 \\
(0.388)\end{array}$ & $\begin{array}{l}-0.626 \\
(0.850)\end{array}$ \\
\hline Assigned Treatment $*$ Test Score ${ }^{\wedge} 2$ & & & & & $\begin{array}{c}0.012 \\
(0.011)\end{array}$ & $\begin{array}{c}0.036 \\
(0.053)\end{array}$ \\
\hline Assigned Treatment $*$ Test Score^3 & & & & & & $\begin{array}{c}-0.001 \\
(0.001)\end{array}$ \\
\hline Constant & $\begin{array}{c}-1.316 \\
(6.633) \\
\end{array}$ & $\begin{array}{l}-3.666 \\
(6.627) \\
\end{array}$ & $\begin{array}{c}-4.410 \\
(6.681) \\
\end{array}$ & $\begin{array}{c}-5.450 \\
(6.708) \\
\end{array}$ & $\begin{array}{r}-4.197 \\
(6.931) \\
\end{array}$ & $\begin{array}{l}-6.143 \\
(7.210) \\
\end{array}$ \\
\hline Observations & 3335 & 3335 & 3335 & 3335 & 3335 & 3335 \\
\hline Adjusted R-squared & 0.246 & 0.250 & 0.250 & 0.249 & 0.250 & 0.249 \\
\hline
\end{tabular}

Notes: The Table reports OLS estimates. The dependent variable is Credits. In all regressions we control for field of study and province dummies. Standard errors (reported in parentheses) are corrected for heteroskedasticity. The symbols ***, **, * indicate that coefficients are statistically significant, respectively, at the 1,5 , and 10 percent level.

In Table 7 we report the same specifications reported in Table 6, but instead of using the continuous measure of procrastination we consider the two dummy variables Slight Procrastination and Heavy Procrastination, jointly with the respective interactions with Assigned Treatment (control variables are not reported to save space).

In all specifications we find that being assigned to treatment does not produce statistically significant effects on students who do not procrastinate. The effect is imprecisely estimated also for students who slightly procrastinate. On the other hand, we find a positive and highly statistically significant effect of remedial courses on students who heavily procrastinate. For these students being assigned to treatment leads to about 8 credits more in the first two years at university. The effect is not small if we consider that students who heavily procrastinate have acquired on average only 41 credits. 
Table 7. Remedial Courses and Procrastination. Regression Discontinuity Estimates. Intention to Treat effects

\begin{tabular}{|c|c|c|c|c|c|c|}
\hline & $(1)$ & $(2)$ & $(3)$ & $(4)$ & $(5)$ & $(6)$ \\
\hline \multirow[t]{2}{*}{ Assigned Treatment } & 0.310 & 0.998 & 2.397 & 1.716 & 2.798 & 4.237 \\
\hline & $(3.678)$ & $(3.672)$ & (3.953) & $(3.700)$ & $(4.209)$ & $(4.722)$ \\
\hline \multirow[t]{2}{*}{ Ass. Treatment*(Slight Procrastin.) } & 2.622 & 2.321 & 2.328 & 2.188 & 2.414 & 2.463 \\
\hline & $(3.748)$ & $(3.729)$ & $(3.730)$ & $(3.737)$ & $(3.730)$ & $(3.733)$ \\
\hline \multirow[t]{2}{*}{ Ass. Treatment*(Heavy Procrastin.) } & $8.513 * *$ & $7.990 * *$ & $8.016 * *$ & $7.857 * *$ & $8.112 * *$ & $8.175^{* *}$ \\
\hline & $(3.797)$ & $(3.787)$ & $(3.787)$ & $(3.798)$ & $(3.790)$ & $(3.791)$ \\
\hline \multirow[t]{2}{*}{ Slight Procrastination } & $-6.359 * *$ & $-6.305^{* *}$ & $-6.227 * *$ & $-6.227 * *$ & $-6.260 * *$ & $-6.332 * *$ \\
\hline & $(2.612)$ & $(2.602)$ & $(2.607)$ & (2.608) & $(2.607)$ & $(2.611)$ \\
\hline \multirow[t]{2}{*}{ Heavy Procrastination } & $-18.457 * * *$ & $-18.117 * * *$ & $-18.039 * * *$ & $-18.064 * * *$ & $-18.080 * * *$ & $-18.153^{* * *}$ \\
\hline & $(2.724)$ & $(2.723)$ & $(2.729)$ & $(2.731)$ & $(2.730)$ & $(2.732)$ \\
\hline \multirow[t]{2}{*}{ Test Score } & $0.469 * * *$ & $0.464 * * *$ & $0.570^{* * *}$ & $0.745^{* * *}$ & $0.592 *$ & $1.173 *$ \\
\hline & $(0.073)$ & $(0.071)$ & $(0.124)$ & $(0.103)$ & $(0.310)$ & $(0.711)$ \\
\hline Observations & 3335 & 3335 & 3335 & 3335 & 3335 & 3335 \\
\hline Adjusted R-squared & 0.242 & 0.246 & 0.246 & 0.245 & 0.246 & 0.246 \\
\hline
\end{tabular}

Notes: The Table reports OLS estimates. The dependent variable is Credits. In all regressions we control for Female, High School Grade, Lyceum, Older Student, field of study and province dummies. Standard errors (reported in parentheses) are corrected for heteroskedasticity. The symbols ***, **, * indicate that coefficients are statistically significant, respectively, at the 1,5 , and 10 percent level.

In Figure 1 we show the intention to treat effects separately for students with different propensities to procrastinate. The circles represent the means of the dependent variable (Credits) for students with a given Test Score level. In the Figure are presented the predicted values from a model explaining Credits in relation to the Assigned Treatment, controlling for a quadratic function of Test Score (specification 2 of Table 7), for students who do not procrastinate (green dotted line), students who slightly procrastinate (red dashed line) and students who heavily procrastinate (blue solid line). The vertical line at the value of zero of the Test Score denotes the cut-off point defined by the assignment rule. It is possible to see a jump in the relationship between the Credits and the Test Score in the proximity of the cut-off point for students who slightly and heavily procrastinate: these students when assigned to the treatment (just below the cutoff point) earn more credits than students just above the cutoff point. On the other hand, no significant jump emerges for students who do not procrastinate. 


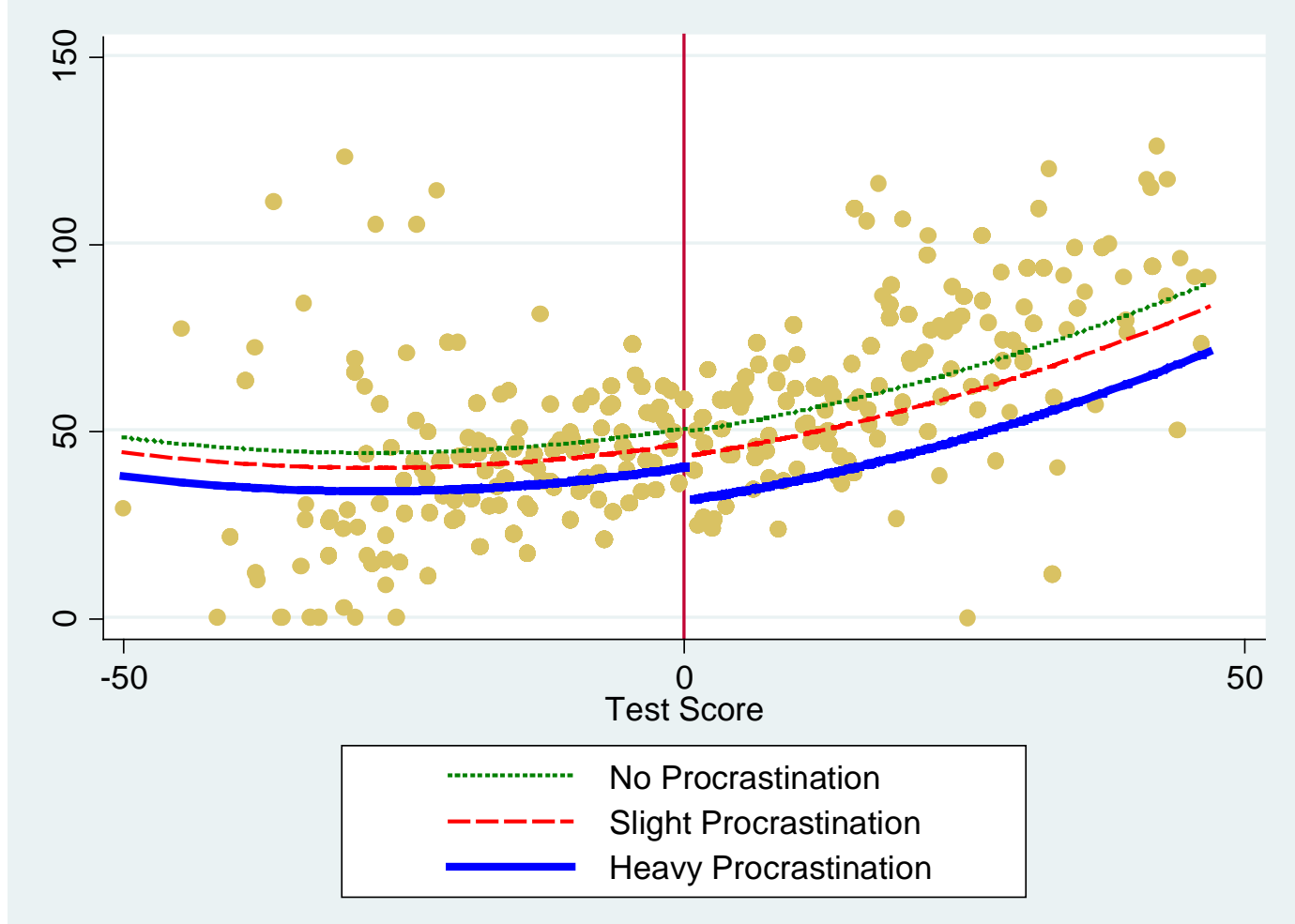

Figure 1. Intention to Treat Effects. Credits and Test Score for different propensity to procrastinate

\subsection{Fuzzy Regression Discontinuity: IV estimates}

In this section we report Two Stage Least Squares (TSLS) estimates obtained applying a Fuzzy Regression Discontinuity Design. First Stage estimation results are reported in Panel B of Table 8 and confirm that, controlling for flexible functions of Test Score, the assigned treatment strongly determines the effective treatment.

Considering the Two-Stage Least Squares Estimates, in column (1) in which we consider a linear function of Test Score, we find that having attended 100 hours of remedial courses leads to an average of about 6.5 more credits for students with an average tendency to procrastinate (this effect is statistically significant at the 1 percent level). The effect increases of 2.2 additional credits for students with a tendency to procrastinate one point higher than the average. ${ }^{20}$ Very similar results are obtained in columns (2) and (3) in which we control respectively for a second and a third order polynomial of Test Score.

In columns (4), (5) and (6) we use our dummy variables as measures of procrastination controlling, respectively, for a first, second and third order polynomial of Test Score. We find again that the beneficial effect of the remedial program is mainly concentrated among students who heavily procrastinate.

\footnotetext{
${ }^{20}$ The estimated coefficients represent the average effect of remedial courses on those individuals who received treatment because they scored just below the cutoff point in the placement test (Local Average Treatment Effect or LATE).
} 
Table 8. Fuzzy Regression Discontinuity Estimates of Remedial Courses Impact on Credits. TSLS Estimates.

$\begin{array}{llllll}(1) & (2) & (3) & (4) & \text { (5) } & \text { (6) }\end{array}$

Panel A: Two-Stage Least Squares Estimates

\begin{tabular}{|c|c|c|c|c|c|c|}
\hline Effective Treatment & $\begin{array}{c}6.507 * * * \\
(2.477)\end{array}$ & $\begin{array}{c}6.903^{* * *} \\
(2.457)\end{array}$ & $\begin{array}{c}9.365 * * * \\
(3.251)\end{array}$ & $\begin{array}{c}1.487 \\
(4.390)\end{array}$ & $\begin{array}{c}2.312 \\
(4.373)\end{array}$ & $\begin{array}{c}5.082 \\
(4.967)\end{array}$ \\
\hline Effective Treatment*(Procrastination) & $\begin{array}{c}2.242^{* *} \\
(0.917)\end{array}$ & $\begin{array}{c}2.194 * * \\
(0.916)\end{array}$ & $\begin{array}{c}2.330^{* *} \\
(0.925)\end{array}$ & & & \\
\hline Effective Treatment*(Slight Procrast.) & & & & $\begin{array}{c}2.309 \\
(4.098)\end{array}$ & $\begin{array}{c}1.918 \\
(4.078)\end{array}$ & $\begin{array}{c}1.577 \\
(4.095)\end{array}$ \\
\hline Effective Treatment*(Heavy Procrast.) & & & & $\begin{array}{l}9.505^{* *} \\
(4.240)\end{array}$ & $\begin{array}{c}8.927 * * \\
(4.226)\end{array}$ & $\begin{array}{c}8.947 * * \\
(4.226)\end{array}$ \\
\hline Procrastination & $\begin{array}{c}-4.608^{* * * *} \\
(0.606)\end{array}$ & $\begin{array}{c}-4.542 * * * \\
(0.606)\end{array}$ & $\begin{array}{c}-4.527^{* * * *} \\
(0.607)\end{array}$ & & & \\
\hline Slight Procrastination & & & & $\begin{array}{c}-6.322 * * \\
(2.609)\end{array}$ & $\begin{array}{c}-6.268^{* *} \\
(2.600)\end{array}$ & $\begin{array}{c}-6.145^{* *} \\
(2.607)\end{array}$ \\
\hline Heavy Procrastination & & & & $\begin{array}{c}-18.487 * * * \\
(2.721)\end{array}$ & $\begin{array}{c}-18.152^{* * *} \\
(2.721)\end{array}$ & $\begin{array}{c}-18.036^{* * * *} \\
(2.727)\end{array}$ \\
\hline Test Score & $\begin{array}{c}0.516^{* * *} \\
(0.084)\end{array}$ & $\begin{array}{c}0.513^{* * *} \\
(0.082)\end{array}$ & $\begin{array}{c}0.678^{* * * *} \\
(0.154)\end{array}$ & $\begin{array}{c}0.506 * * * \\
(0.084)\end{array}$ & $\begin{array}{c}0.504^{* * *} \\
(0.082)\end{array}$ & $\begin{array}{c}0.677 * * * \\
(0.153)\end{array}$ \\
\hline Test Score $\wedge 2$ & & $\begin{array}{c}0.008^{* * *} \\
(0.002)\end{array}$ & $\begin{array}{c}0.009 * * * \\
(0.002)\end{array}$ & & $\begin{array}{c}0.008 * * * \\
(0.002)\end{array}$ & $\begin{array}{c}0.009 * * * \\
(0.002)\end{array}$ \\
\hline Test Score^3 & & & $\begin{array}{l}-0.000 \\
(0.000)\end{array}$ & & & $\begin{array}{l}-0.000 \\
(0.000)\end{array}$ \\
\hline
\end{tabular}

Panel B: First Stage for Effective Treatment

\begin{tabular}{lcccccc}
\hline & & & & & & \\
Assigned Treatment & $0.812^{* * *}$ & $0.830^{* * *}$ & $0.745^{* * *}$ & $0.737 * * *$ & $0.741^{* * *}$ & $0.676^{* * *}$ \\
& $(0.025)$ & $(0.025)$ & $(0.031)$ & $(0.046)$ & $(0.045)$ & $(0.049)$ \\
R-squared & 0.572 & 0.605 & 0.574 & 0.571 & 0.571 & 0.573 \\
First-Stage F-statistics & 529.04 & 551.09 & 299.55 & 362.11 & 377.59 & 206.74 \\
$p$-value & 0.000 & 0.000 & 0.000 & 0.000 & 0.000 & 0.000 \\
\hline Observations & 3335 & 3335 & 3335 & 3335 & 3335 & 3335 \\
\hline \hline
\end{tabular}

Notes: The Table reports IV estimates. The dependent variable is Credits. In all regressions we control for Female, High School Grade, Lyceum, Older Student, field of study and province dummies. Standard errors (reported in parentheses) are corrected for heteroskedasticity. The symbols $* * *, * *, *$ indicate that coefficients are statistically significant, respectively, at the 1,5 , and 10 percent level.

Similar results are obtained when we use Local Linear Regressions focusing on three different bandwidths considering respectively students with a Test Score ranging from -10 to $+10,-7 /+7$ and $-5 /+5$ points around the cut-off point. Results from Local Linear Regressions are reported in Table 9. The estimates barely change in terms of statistical significance but become larger in magnitude at increasingly narrow windows. In the first three specifications, remedial courses produce an increase in credits ranging from 12 to 20 (according to the window) for students with an average tendency to procrastinate and an increase of 14-24 credits for those with a tendency to procrastinate above the mean. In specifications (4), (5) and (6), we again find that the effects of the remedial program are concentrated among students who heavily procrastinate. 
Table 9. Fuzzy Regression Discontinuity Estimates. Local Linear Regressions

\begin{tabular}{|c|c|c|c|c|c|c|}
\hline & (1) & (2) & (3) & (4) & (5) & (6) \\
\hline & $-10 /+10$ & $-7 /+7$ & $-5 /+5$ & $-10 /+10$ & $-7 /+7$ & $-5 /+5$ \\
\hline Effective Treatment & $\begin{array}{c}12.006^{* *} \\
(5.308)\end{array}$ & $\begin{array}{c}14.121^{* *} \\
(6.898)\end{array}$ & $\begin{array}{c}20.399 * * \\
(8.886)\end{array}$ & $\begin{array}{c}-1.685 \\
(8.686)\end{array}$ & $\begin{array}{c}2.887 \\
(11.268)\end{array}$ & $\begin{array}{c}3.644 \\
(14.147)\end{array}$ \\
\hline Effective Treatment*(Procrastination) & $\begin{array}{l}2.597^{*} \\
(1.458)\end{array}$ & $\begin{array}{c}2.728 \\
(1.859)\end{array}$ & $\begin{array}{l}4.445^{*} \\
(2.430)\end{array}$ & & & \\
\hline Effective Treatment*(Slight Procrast.) & & & & $\begin{array}{c}13.234^{*} \\
(7.149)\end{array}$ & $\begin{array}{c}9.856 \\
(8.942)\end{array}$ & $\begin{array}{c}14.228 \\
(11.526)\end{array}$ \\
\hline Effective Treatment*(Heavy Procrast.) & & & & $\begin{array}{c}18.474^{* *} \\
(7.210)\end{array}$ & $\begin{array}{c}16.162 * \\
(9.066)\end{array}$ & $\begin{array}{c}24.884^{* *} \\
(11.570)\end{array}$ \\
\hline Procrastination & $\begin{array}{c}-4.343^{* * *} \\
(0.843)\end{array}$ & $\begin{array}{c}-4.349 * * * \\
(1.004)\end{array}$ & $\begin{array}{c}-4.820 * * * \\
(1.242)\end{array}$ & & & \\
\hline Slight Procrastination & & & & $\begin{array}{c}-13.455^{* * *} \\
(3.862)\end{array}$ & $\begin{array}{c}-11.721^{* * *} \\
(4.492)\end{array}$ & $\begin{array}{r}-15.446^{* * *} \\
(5.791)\end{array}$ \\
\hline Heavy Procrastination & & & & $\begin{array}{c}-22.371^{* * *} \\
(3.928) \\
\end{array}$ & $\begin{array}{r}-21.698 * * * \\
(4.634) \\
\end{array}$ & $\begin{array}{r}-26.467 * * * \\
(5.913) \\
\end{array}$ \\
\hline Observations & 1692 & 1260 & 970 & 1692 & 1260 & 970 \\
\hline
\end{tabular}

Notes: The Table reports IV estimates. The dependent variable is Credits. In all regressions we control for Female, High

School Grade, Lyceum, Older Student, field of study and province dummies. Standard errors (reported in parentheses) are corrected for heteroskedasticity. The symbols ***, **, * indicate that coefficients are statistically significant, respectively, at the 1,5 , and 10 percent level.

\section{Concluding Remarks}

Psychologists and social science scholars have shown that individuals confronted with a choice between doing an unpleasant activity today or in the future tend to put-off the work and do it in the future. This behavior can lead to irrational choices that produce severe harm on individual well-being. Present-biased individuals tend to consume too much, to borrow excessively using credit cards, to procrastinate important decisions, such as signing up for retirement plans, to exercise to little, etc..

In this paper we focus the attention on the relationship between present biased preferences and human capital investments. While a number of papers document that self-control and procrastination problems are pervasive among college students (Solomon and Rothblum, 1984; Steel, 2007; Angrist et al. 2009), little is known about the effects these problems produce on performance and on which policies are more effective in helping individuals to overcome them. Among the few exceptions, the works of Mischel, Shoda and Rodriguez (1989), Wong (2008) and Ariely and Wertenbroch (2002), document how procrastination can harm students' performance.

We add to this literature by both analyzing the relationship between procrastination attitudes and academic success and investigating how students with different attitudes toward procrastination react to a policy requiring them to attend some remedial courses.

Our analysis considers a quite large sample of students and relies on a measure of procrastination based on students' actual behavior rather than on survey questions. We measure procrastination with the number of days students take to accomplish an enrollment procedure (since the admission notification) that involves immediate small transaction costs. Given the very short time period (seven weekdays) that students had for finalizing the enrolment procedure (which should imply a discount factor close to 1), our measure is likely to proxy for self-control problems. 
We find that one day of delay in accomplishing the enrollment procedure is associated with a reduction of about 5 of credits acquired by students in their first two years at university. The negative correlation between procrastination and academic performance becomes particularly worrying for students who heavily procrastinate (more than 5 days of delay): these students acquired about 13 credits less. Results are robust to the inclusion of many controls, including measures of students' ability, family background, motivation and area of residence fixed effects.

The way to handle procrastination problems and which educational policies are more beneficial to procrastinators are important issues. Binding deadlines have been shown to produce positive effects, but also other policies might help students at recognize their problems and manage them. For instance, Carrel and Sacerdote (2013) show that a program offering monetary incentives and mentoring activities to high school students is especially helpful for individuals who tend to procrastinate.

Following this approach, we have investigated whether a policy requiring students to attend some remedial courses at the beginning of the academic year has produced different effects according to students' propensity to procrastinate. Relying on the cutoff rule adopted to assign students to the treatment, we estimate both Intention to Treat and Local Average Treatment effects and we find that students with the strongest tendency to procrastinate are those who mostly benefit from the remedial program. Probably this is due to the fact that remedial courses made soon salient to attending students the need to work hard to overcome their educational gaps. It could also be that remedial courses, organized in small classes and imposing deadlines for studying activities, have helped students to change their studying habits.

Our evidence suggests that procrastination produces strong negative effects on student performance, but also policies not directly aimed at solving self-control problems can be particularly helpful for procrastinators.

\section{References}

Akerlof, G. (1991), “Procrastination and obedience”, American Economic Review, 81(2), 1-19.

Angeletos, G. M., Laibson, D., Repetto, A., Tobacman, J., and Weinberg, S. (2001), "The hyperbolic consumption model: Calibration, simulation, and empirical evaluation”, Journal of Economic Perspectives, 15(3), 47-68.

Angrist, J., Lang, D., and Oreopoulos, P. (2009), "Incentives and services for college achievement: Evidence from a randomized trial”, American Economic Journal: Applied Economics, 1(1), 136-163.

Angrist, J., Pischke, J., (2009), Mostly Harmless Econometrics, Princeton University Press.

Ariely, D., and Wertenbroch, K. (2002), "Procrastination, Deadlines, and Performance: Self-Control by Precommitment.” Psychological Science, 13(3): 219-24.

Ausubel, L. M. 1999. “Adverse Selection in the Credit Card Market.” Unpublished.

Bettinger E, Long B (2009) Addressing the needs of under-prepared college students: does college remediation work? Journal of Human Resources, 44:736-771

Bettinger, E. and Slonim, R. (2007), “Patience among Children,” Journal of Public Economics 91 (1-2), 343363.

Cadena, B. and Keys, B. (2011), "Human Capital and the Lifetime Costs of Impatience,” Unpublished manuscript, Harris School of Public Policy, University of Chicago.

Calcagno JC, Long B (2010) The impact of postsecondary remediation using a regression discontinuity approach: addressing endogenous sorting and noncompliance. Mimeo 
Carrell, S. E., and Sacerdote, B. (2013). "Late Interventions Matter Too: The Case of College Coaching New Hampshire” (No. w19031). National Bureau of Economic Research.

Castillo, M., Ferraro, P., Jordan J. and Petrie, R. (2011), "The Today and Tomorrow of Kids: Time Preferences and Educational Outcomes of Children”, Journal of Public Economics 95 (11- 12), 1377-85.

Checchi, D., Fiorio, C., Leonardi, M. (2008), "Intergenerational persistence in educational attainment in Italy”, IZA Discussion Papers 3622.

De Paola M. and Scoppa V. (2014), The Effectiveness of Remedial Courses in Italy: A Fuzzy Regression Discontinuity Design, Journal of Population Economics, 27, 2, 365-386.

De Paola, M., and Gioia, F.. 2013, Impatience and Academic Performance. Less Effort And Less Ambitious Goals. Working paper No. 201302..

DellaVigna, S., (2009), "Psychology and Economics: Evidence from the Field", Journal of Economic Literature, 47:2, 315-372.

DellaVigna, S., and U. Malmendier (2006), "Paying Not to Go to the Gym.” American Economic Review, 96(3): 694-719.

Dewitte, S. and Schouwenburg, H. (2002), Procrastination, temptations, and incentives: the struggle between the present and the future in procrastinators and the punctual, European Journal of Personality, vol. 16, no. 6, 469-489.

Dornbusch, R., Gentilini, A., and Giavazzi, F. (2000). "Italian Labor Force Participation: Disguised Unemployment on Campus". unpublished, Igier, Bocconi University.

Golsteyn, B., Grönqvist, H., Lindahl, L., 2013, “Time Preferences and Lifetime Outcomes”, IZA DP No. 7165, January 2013

Grubb, M. D. (2009) “Selling to Overconfident Consumers”, American Economic Review, Vol. 99, No. 5, pp. 1770-1807.

Heckman, J. J., and Rubinstein, Y. (2001). "The importance of noncognitive skills: Lessons from the GED testing program”, American Economic Review, 91(2), 145-149.

Howell, A.J., Watson, D.C., Powell, R.A. and Buro, K. (2006), Academic procrastination: the pattern and correlates of behavioural postponement, Personality and Individual Differences, vol. 40, pp. 15191530

Imbens, G., and Lemieux, T. (2008), “Regression Discontinuity Designs: A Guide to Practice”, Journal of Econometrics, 142(2), 615-635.

Laibson, D. (1997), “Golden Eggs and Hyperbolic Discounting”, Quarterly Journal of Economics, 112(2): 443-77

Martorell P,McFarlin I (2011) Help or hindrance? The effects of college remediation on academic and labor market outcomes. Rev Econ Stat. doi:10.1162/REST_a_00098

Mischel, W., Shoda, Y., Rodriguez, M., (1989), “Delay of Gratification in Children”, Science; May 26, 1989; 244, 4907.

Novarese, M., Di Giovinazzo, V. (2013), “Solerzia e successo accademico”, MPRA Paper No. 45008.

O’Donoghue, T., and M. Rabin. (1999). "Doing It Now or Later, American Economic Review, Vol. 89, No. 1 (Mar., 1999), pp. 103-124.

O’Donoghue, T., and M. Rabin. (2001). “Choice and Procrastination.” Quarterly Journal of Economics, 116(1): 121-60.

Reuben, E., Sapienza, P., and Zingales, L. (2007), Procrastination and impatience (No. w13713). National Bureau of Economic Research.

Solomon, L.J. and Rothblum, E.D. (1984), Academic Procrastination: frequency and Cognitive-Behavioral Correlates, Journal of Counseling Psychology, vol. 31, no. 4, pp. 503-509.

Wong, Wei-Kang, (2008), "How much time-inconsistency is there and does it matter? Evidence on selfawareness, size, and effects”, Journal of Economic Behavior and Organization, 68.3 (2008): 645656. 